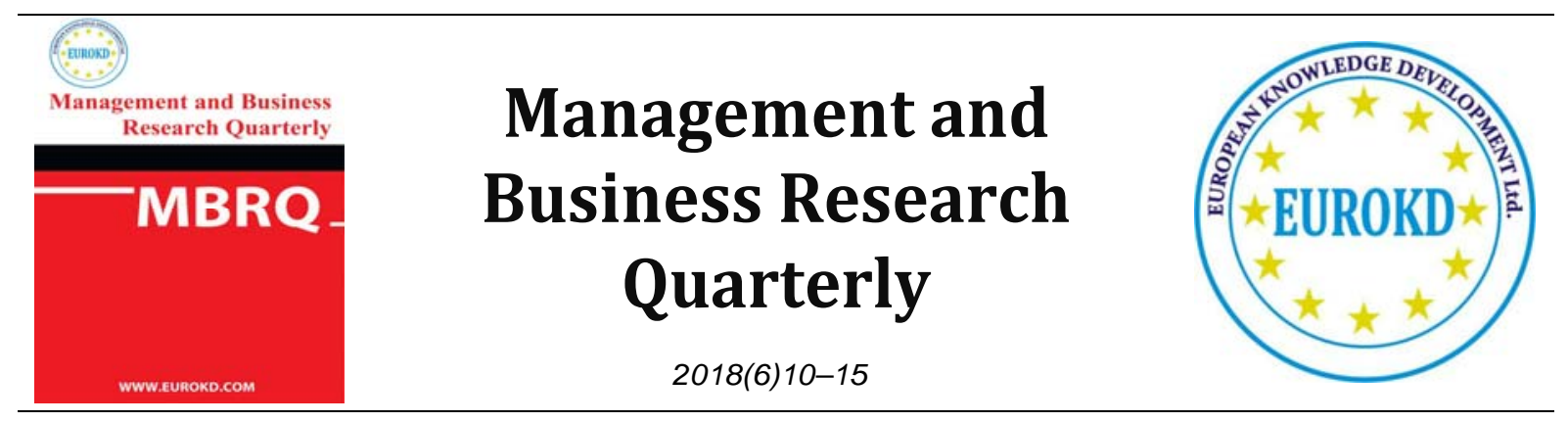

\title{
Digitalization on Boards: Evidence from the Baltic Public Listed Companies
}

\author{
Emil Velinov ${ }^{1, *}$, Milan Maly ${ }^{2}$, Milomir Vojvodic $^{2}$ \\ 1 "RISEBA" University of Business, Arts and Technology, Riga Skoda Auto University, Mlada Boleslav, Czech \\ ${ }^{2}$ University of Economics, Prague, Czech
}

Received 17 June 2018 Accepted 26 August 2018

\begin{abstract}
The paper investigates one of the phenomena of current era- digitalization within the top management teams in the Baltic Public Listed companies. The paper sheds a light on senior management digitalization competences as in the public listed companies very small percentage of the board members possess digitalization. The paper argues that digitalization on the boards is linked with the level of diversity and internationalization of the top management team members. The empirical data of the paper have been collected from online available database on public listed companies in Estonia, Latvia and Lithuania. Research findings show that there is no correlation between TMT digitalization competences and company performance. Study results illustrate that there is no significant relationship between TMT digitalization and level of company internationalization. The paper findings outline that majority of the public listed companies in the Baltic states do not have Chief Information Officer or Senior Digitalization Manager as the companies exist in digitalized World full of changes. The paper identifies aspects of digitalization effects on company performance and level of internationalization and diversity. This research draws attention on top management team's digitalization skills and competences as one of the key skills needed for each senior manager nowadays.
\end{abstract}

Keywords: Digitalization, Top Management Teams, Public Listed Companies, Baltic States

\section{Introduction}

Nowadays in the era of digitalization and high technologies, the business world is quite turbulent and companies around the globe should manage the constant and turbulent changes not only among their customers but within the organizations as well. In this aspect, it is a very important for the companies to manage the technological changes inside the company by having on board competent 
and skilled senior managers, who could lead successful transformation of the company. Therefore, there is a high need of top managers, who are masters in Digitalization and IT and they can manage the risk for the company.

Stemming from these facts, our motivation to write this paper was because the emerging pattern of digitalization among different industries and regions across the globe and current business needs triggered by the IT security, customer requests and other stakeholders' requirements.

On the other hand, business organizations, which are pushing much into sustainable business development in today's constantly fluctuating competitive environment, strive for continuously seeking for ways to improve its operations. In such a situation, it is inevitable to concentrate on the prudential use of all available resources in the company (Velinov et al., 2018).

The top management team's theory argues that a firm's strategic decisions and subsequent results are reflections of the features of its elite management, and particularly its senior management structures (TMT; Hambrick \& Mason, 1984; Certo, 2006). As the TMT social adaptation is a crucial firm capability (Carpenter, 2002) and it has very important components of a strategic asset and digitalization, TMT social integration might be an important mechanism through which a senior management approach apprehends a organization's advantageous benefits. Chief Digitalization officers' positions have been established, how CDOs fulfill their positions and how they can be successfully installed to guide organizations through their digital transformation (Barnir et al., 2013). Digitization possesses extended impact not only on the way of working, but it also fosters the temp of transformation, which companies are dealing with. Both implications steer to three main demands that have to be tackled to be successful: new capabilities and competencies, new ways of leadership, and new firm resources. Depending on the degree to which organizations meet these demands they would possibly improve their culture towards a 'digital thinking'. On the other hand, digital transformation efforts and programs are facing big hurdles to reach the expected business benefits. Several studies in the literature explicitly pinpoint the importance of managing people and organizational challenges in the business environment of digital changes.

\section{Methodology}

For the purpose of the study, dataset has been collected through the online tool Webpool, which is very common for gathering corporate data from the public listed companies in Baltics. Moreover, we have used LinkedIn business social network in order to conduct the online survey as some top managers from the Baltic companies are using the platform actively in order to recruit nationals from Baltics and abroad for companies' operations in Baltic states. Therefore, we found quite practical to gather data through LinkedIn as well. In the literature some authors outline that the companies nowadays use actively digital platforms and social networks in order to run their business smoothly and more efficiently when it comes to internationalization and head hunting executives (Rogers, 2016). The period of the dataset consists of 37 companies and more than one hundred executive profiles from the Estonian, Latvian and Lithuanian public listed firms. We have collected primary data through the online questionnaires digitalization skills of TMT members and their perception on digitalization. 


\section{Findings}

In the table 1 below we have run the descriptive statistics, which depicts several findings in the paper. Even though, majority of the Baltic public listed companies are operating regionally and internationally, only few of them have on board Chief Strategy Officer, Chief Digitalization Officer or Chief Information Officer. However, the questioned top managers pointed out the necessity of having at least one of these three eventual executive positions as their companies highly need to increase upper echelons awareness of digitalization and GDPR (Yuan, 2014). Moreover, the questioned senior managers believe that higher digitalization skills among the top management teams could bring higher company performance. However, digitalization skills are not only linked to IT skills, but it includes transformational leadership and interpersonal communication skills as well (Wunderich, 2017). Furthermore, interestingly the existing Chief Information Officer from the Baltic public listed companies do not have previous dominant function regardless they are responsible for the data governance and GDPR implementation. It is self-explanatory matter as that digitalization is not only about technology and innovation, but it is about people as well (Kohnke, 2017). The paper findings show that the CIO role includes not only IT skills, but leadership and soft skills, which is considered by the top management as an important and highly demanded for the TMT members efficiency and cooperation in the post bureaucratic era of management and business (Gerth, 2016).

Table 1. Descriptive Statistics

\begin{tabular}{|l|c|c|c|c|}
\hline Variable & Mean & Std. Dev. & Min & Max \\
\hline Company Internationalization & 0.75 & 0.4399413 & 0 & 1 \\
\hline $\begin{array}{l}\text { Existance of Chief Information Officer or Senior Digitalization } \\
\text { Manager }\end{array}$ & 0.516129 & 0.5080005 & 0 & 1 \\
\hline $\begin{array}{l}\text { TopManager/Founder responsible for the Data Governance } \\
\text { possession of IT education? }\end{array}$ & 0.59375 & 0.4989909 & 0 & 1 \\
\hline $\begin{array}{l}\text { Top Manager/Founder responsible for the Data Governance } \\
\text { possesses dominant function in IT }\end{array}$ & 0.71875 & 0.4568034 & 0 & 1 \\
\hline $\begin{array}{l}\text { IT skills of the Top Managers having positive impact on company } \\
\text { performance }\end{array}$ & 0.7741935 & 0.4250237 & 0 & 1 \\
\hline $\begin{array}{l}\text { IT skills of the Top Managers and their impact on company } \\
\text { internationalization }\end{array}$ & 0.78125 & 0.4200134 & 0 & 1 \\
\hline TMT IT skills and their impact on company performance & 0.8709677 & 0.3407771 & 0 & 1 \\
\hline Number of employees & 2.28125 & 0.8125775 & 1 & 3 \\
\hline Type of Industry & 3.78125 & 1.995711 & 1 & 6 \\
\hline HQ Location & 2.34375 & 1.842323 & 1 & 6 \\
\hline
\end{tabular}

Source: Author 
Table 2. Correlation analysis among the variables

\begin{tabular}{|c|c|c|c|c|c|c|c|c|c|c|}
\hline & Int & CIForSDM & ITeduc & DomFun T & PosImp r & PosImp t & PosImp f & NofEmpl & Indust 1 & Country \\
\hline Int & 1.0000 & & & & & & & & & \\
\hline CIForSDM & 0.2614 & 1.0000 & & & & & & & & \\
\hline ITeduc & 0.2233 & 0.0981 & 1.0000 & & & & & & & \\
\hline DomFuncIT & 0.0124 & 0.0213 & 0.3125 & 1.0000 & & & & & & \\
\hline PosImpPer & -0.0892 & -0.3231 & 0.4779 & 0.0657 & 1.0000 & & & & & \\
\hline PosImpInt & -0.3182 & -0.2224 & 0.2233 & 0.1927 & 0.5076 & 1.0000 & & & & \\
\hline PosImpHigh $\sim f$ & -0.2256 & -0.1863 & 0.0995 & 0.2006 & 0.2894 & 0.4754 & 1.0000 & & & \\
\hline NofEmpl & -0.1192 & -0.4655 & 0.0526 & 0.1477 & 0.4446 & 0.1859 & -0.0305 & 1.0000 & & \\
\hline Industry1 & 0.2578 & 0.4415 & -0.0428 & 0.1062 & -0.0820 & -0.2245 & 0.1686 & -0.3668 & 1.0000 & \\
\hline Country & -0.3005 & -0.0531 & -0.1448 & -0.2121 & -0.1162 & 0.0139 & 0.4479 & -0.1255 & 0.2437 & 1.0000 \\
\hline
\end{tabular}

Source: Author

The highest correlations are highlighted, but none of them exceed 0.8 , hence we do not have multicollinearity between variables.

Table 3. Reliability: Cronbach's alpha and Average Item-Total Correlations (or Item-rest correlations in STATA)

\begin{tabular}{|c|c|c|c|c|c|c|c|}
\hline Item & Obs & Sign & $\begin{array}{l}\text { item-test } \\
\text { corr. }\end{array}$ & $\begin{array}{l}\text { item-rest } \\
\text { corr. }\end{array}$ & $\begin{array}{l}\text { interitem } \\
\text { corr. }\end{array}$ & alpha & Label \\
\hline CIForSDM & 31 & - & 0.5647 & 0.3847 & 0.1694 & 0.6200 & $\begin{array}{l}\text { Does in your company exist position of Chief Information } \\
\text { officer or Senior Digit }\end{array}$ \\
\hline ITeduc & 32 & + & 0.4944 & 0.3040 & 0.1785 & 0.6348 & $\begin{array}{l}\text { Does the Top Manager/Founder responsible for the Data } \\
\text { Governance have IT educati }\end{array}$ \\
\hline DomFuncIt & 32 & + & 0.4859 & 0.2955 & 0.1806 & 0.6381 & $\begin{array}{l}\text { Does the Top Manager/Founder responsible for the Data } \\
\text { Governance have dominant } f\end{array}$ \\
\hline PosImper & 31 & + & 0.7279 & 0.5996 & 0.1396 & 0.5649 & $\begin{array}{l}\text { Do you think that IT skills of the Top Managers have } \\
\text { positive impact on company }\end{array}$ \\
\hline PosImpInt & 32 & + & 0.6286 & 0.4687 & 0.1552 & 5951 & $\begin{array}{l}\text { Do you think that IT skills of the Top Managers have } \\
\text { positive impact on company }\end{array}$ \\
\hline PosImpHigh f & 31 & + & 0.3673 & 0.1609 & 0.1989 & 0.6651 & $\begin{array}{l}\text { Do you consider in general that higher IT skills possess } \\
\text { Top Management Teams' m }\end{array}$ \\
\hline NofEmpl & 32 & - & 0.6472 & 0.4931 & 0.1533 & 0.5916 & What is the number of employees at your company? \\
\hline Industry1 & 32 & + & 0.4702 & 0.2774 & 0.1824 & 0.6410 & What is the industry of your comany? \\
\hline Country & 32 & + & 0.2778 & 0.0630 & 0.2150 & 0.6866 & Country of Head Quarter of your company? \\
\hline Test scale & & & & & 0.1748 & 0.6559 & mean(standardized items) \\
\hline
\end{tabular}

Source: Author

The dataset reliability was verified with "Cronbach's Alpha (Cronbach 1951), that weights the reliability of a psychometric scale consisting of variables (Table 3). Alpha provides lower bound on reliability and calculates the average correlations of a set of items or covariances for all pairs of 
variables. Therefore, it is realistically to evaluate the internal compatibility of the test. Parallelly, it could be more practical to calculate for item-rest correlations (Nunnally and Bernstein 1994), that represent the correlation between an item or variable and the scale or subscale, which is formed by all other items. Furthermore, called an item-total correlation the item-rest correlation test is calculated in order to verify if any item in the set of tests is inconsistent with the averaged behavior of the other items. Several authors as Weber, Blais and Betz (2002) argue that it is realistic to involve only items with an item-rest correlation more than 0.3 to obtain a reliable questionnaire, otherwise the items with item-rest correlation lower than 0.3 have to be excluded from the analysis. Cronbach's alpha is 0,66 , which shows that the model is not reliable because, according to the STATA Manual, it supposes to be over 0,80. Therefore, companies, which have CDOs, CIOs or CTOs do not necessary have higher firm performance than the public listed companies, which don't have the latter positions.

"Users of alpha demand particular standard for refereeing values of $\alpha$. As we have withdrew from Nunnally and Bernstein $(1994,265)$ : In the early phases of research, mild reliability of 0.70 or higher would be enough; values in higher than 0.80 often are meaningless and waste time and funds. On the other hand, where measurements on individuals are of interest, a reliability of 0.80 might not be almost high sufficiently. Even with a reliability of 0.90, the standard error of measurement is almost one-third as big as the standard deviation of test scores; a reliability of 0.90 is the minimum that supposed to be tolerated, and a reliability of 0.95 should be taken as the desirable standard."

\section{Conclusions}

The paper findings outline that majority of the public listed companies in the Baltic states do not have Chief Information Officer or Senior Digitalization Manager as the companies exist in digitalized World full of changes. Top Management Teams should ensure that Chief Digitalization Officers (CDOs) have sufficient authority. Majority of CDOs in our study have successfully conceived digital transformation strategies and implemented the associated digital initiatives in a timely manner. The paper identifies aspects of digitalization effects on company performance and level of internationalization and diversity. This research draws attention on top management team's digitalization skills and competences as one of the key skills needed for each senior manager nowadays (Fitzgerald, 2013). In the future, it would be quite interesting to observe the future development of digitalization skills among the TMT members and continuation of interactions between CDOs and the other top executives in order to be achieved synergy and higher team performance. However, there will be many obstacles in front of the Baltic public listed companies in the process of increasing digitalization awareness such as GDPR implementation specifics, IT security concerns, level of digitalization skills among the TMT members but as well as the middle and lower level management.

\section{References}


Barnir, A., Gallaugher, J.M., Auger, P., (2003). Business process digitization, strategy, and the impact of firm age and size: the case of the magazine publishing industry. Journal of Business Venturing. 18, 789-814.

Cetindamar, D., Phaal, R., \& Probert, D. R. (2016). Technology management as a profession and the challenges ahead. Journal of Engineering and Technology Management, 41, 1-13.

Certo, S. T., Lester, R. H., Dalton, C. M., \& Dalton, D. R. (2006). Top management teams, strategy, and financial performance: A meta-analytic examination. Journal of Management Studies, vol. 43.

Carpenter, M. A. (2002). The implications of strategy and socio context for the relationship between top management team diversity and firm performance. Strategic Management Journal, vol. 23.

Fitzgerald et al., (2013). Embracing Digital Technology. MIT Sloan Management Review.

Gerth, A. B., \& Peppard, J. (2016). The dynamics of CIO derailment: How CIOs come undone and how to avoid it. Business Horizons, 59(1), 61-70.

Hambrick D.C., Mason P.A. (1984) 'Upper echelons: the organization as a reflection of its top managers'. Academy of Management Review 9(2):193-205

Hambrick, D. C. (2007). TMTs theory: An update. Academy of Management Review, vol. 32.

Holmlund, M., Strandvik, T., \& Lähteenmäki, I. (2017). Digitalization challenging institutional logics: Top executive sense making of service business change. Journal of Service Theory and Practice, 27(1), 219-236.

Kohnke, O. (2017). It's not just about technology: the people side of digitization. In shaping the digital enterprise (pp. 69-91). Springer, Cham.

Korhonen, J.J., (2015). The Changing Role of the CIO. Published in: Research report, Aalto University. Department of Computer Science.

Parthasarthy, R., Sethi, S.P., (1992). The Impact of Flexible Automation on Business Strategy and Organizational Structure. Academy of Management Review. 17, 86-111.

Rogers, D., (2016). The Digital Transformation Playbook: Rethink Your Business for the Digital Age. Columbia University Press.

Velinov, E., Vassilev, V., Denisov, I. (2018). Holacracy and Obliquity: contingency management approaches in organizing companies. Problems and Perspectives in Management, 16(1), 330-335.

Wunderlich, N., \& Beck, R. (2017). We've got the power-the relevance of leadership and organizational IT capabilities in the fully digitalized business era.

Yuan X, Guo Z, Fang EE (2014). 'An examination of how and when the top management team matters for firm innovativeness: the effects of TMT functional backgrounds’. Innovation Management Policy Practice 16(3):323-342 